\title{
Pengujian Slag Nikel Sebagai Pengganti Agregat Pada Campuran HRS-Base
}

\author{
Utami Arruantasik Demmalino *1, Cyntia Sielviana Widya Lambe ${ }^{* 2}$, Alpius*3, Rais Rachman*4 \\ *1,2 Mahasiswa Prodi Teknik Sipil, Universitas Kristen Indonesia Paulus, Makassar, Indonesia \\ utamiarruann@gmail.com , cyntiasielvianawidyalambe95@yahoo.com \\ *3,4 Dosen Prodi Teknik Sipil, Universitas Kristen Indonesia Paulus, Makassar, Indonesia \\ Rais.Rachman@gmail.com , alpiusnini@yahoo.com
}

\begin{abstract}
ABSTRAK
Penelitian ini dimasukkan untuk menguji karakteristik campuran Lataston HRS-Base dengan memanfaatkan slag nikel berdasarkan pengujian laboratorium. Hasil penelitian menunjukkan bahwa karakteristik bahan perkerasan berupa slag nikel dari Soroako Kab. Luwu Timur memenuhi spasifikasi sebagai bahan lapisan permukaan jalan. Melalui uji Marshall diperoleh karakteristik campuran Lataston HRS-Base bergradasi senjang dan semi senjang dengan kadar aspal 5,0\%, 5,93\%, 6,35\%, 6,78, dan 7,2\% memenuhi persyaratan. Hasil pengujian Marshall Immertion campuran Lataston HRS-Base bergradasi senjang dan semi senjang pada kadar aspal optimum 6,35\% mendapatkan Indeks Perendaman (IP) / Indeks Kekuatan Sisa (IKS) / Durabilitas campuran sebesar 97,03\% dan 98,00\% Dimana dari hasil penelitian ini dapat ditarik kesimpulan bahwa penggunaan slag nikel sebagai pengganti agregat kasar dapat dimanfaatkan sebagai bahan perkerasan jalan karena memenuhi Standar Spesifikasi Bina Marga.
\end{abstract}

Kata Kunci : Karakteristik Marshall, Lataston HRS-Base, Slag Nikel

\section{ABSTRACT}

The research objective was to examine the characteristics of the Lataston HRS-Base mixture by utilizing nickel slag based on laboratory testing. The results showed that the characteristics of the pavement material in the form of nickel slag from Soroako District. East Luwu meets the specifications of road surface coating material. Through the Marshall test, the characteristics of the Lataston HRS-Base mix were obtained by gradation and semi-gap grading with asphalt content of $5.0 \%, 5.93 \%, 6.35 \%$, 6.78, and $7.2 \%$ and Marshall Immertion mixed Lataston HRS-Base assay results with gaps and semi-gaps graded at optimum asphalt content of $6.35 \%$ get Immersion Index (IP) / Remaining Strength Index (IKS) / Mixed durability of $97.03 \%$ and $98.00 \%$ Wherein the results of this study can be concluded that the use of nickel slag as a substitute for coarse aggregate can be used as a road pavement because it meets the Bina Marga Specifications Standard.

Keywords: Marshall Characteristics, Lataston HRS-Base, Nickel Slag

\section{PENDAHULUAN}

Perkerasan jalan merupakan lapisan perkerasan yang terletak diantara lapisan tanah dasar dan roda kendaraan, yang berfungsi memberikan pelayanan kepada sarana transportasi [1]. Bahan material pembentuk lapisan perkerasan jalan adalah agregat sebagai material utama yang berbengaruh terhadap daya lapisan permukaan jalan dan aspal sebagai bahan pengikat peningkat agregat agar lapisan perkerasan kedap air. Pencampuran perkerasan jalan ini dengan menggunakan Slag nikel yang merupakan agregat bahan sisa hasil pembuangan dari pembakaran dapur listrik yang dihasilkan oleh pabrik tambang.

\section{d. Aspal}

Tujuan penilitian ini adalah untuk mengetahui karakteristik slag nikel sebagai bahan lapisan permukaan jalan pada campuran Lataston (HRSBase), untuk engetahui komposisi campuran Lataston (HRS-Base) yang mengunakan slag nikel sebagai pengganti agregat, untuk mengetahui karakteristik Marshall Campuran Lataston (HRSBase), dan untuk mengetahui berapa indeks kekuatan sisa terhadap Campuran Lataston (HRSBase).

Agregat dikelompokkan menjadi [2] :

a. Agregat kasar, dengan butiran yang tertahan ayakan No. 4.

b. Agegat halus, dengan butiran yang lolos ayakan No 4 tertahan diayakan No.200

c. Bahan pengisi (Filler)

Sifat dan kualitas agregat menentukan kemampuan dalam memikul beban lalu lintas. 
Slag nikel merupakan salah satu limbah padat penambangan dan proses pengelolahan nikel. Jumlah slag nikel makin menumpuk. Karena setiap proses pemurnian satu ton produk nikel menghasilkan limbah padat 50 kalinya, setara 50 ton. Sehingga dari hasil limbah yang cukup banyak,dilakukan penelitian untuk menggunakan limbah padat tersebut sebagai bahan pembentuk beton,baik sebagai agergat kasar dan halus ,ataupun sebagai bahan campuran semen. Sekitar 70\% komposisi kimia terdiri dari Silika 41,47\%, Ferri Oksida 30,44\% dan Aluminia 2,58\%. Dengan komposisi silica yang cukup besar pada slag nikel diharapkan proses hidrasi yang terjadi antara pasta dan semen agregat membentuk interface yang lebih sempurna,sehingga kehancuran beton tidak terjadi pada interface, atau kalaupun terjadi pada interface diperlukan enegri yang cukup tinggi. Adapun pada pembentukan bongkahan slag nikel tersebut ada dua macam terak yang terbentuk yaitu slag nikel yang berpori sekitar 2,835 sehingga penggunaanya dapat digunakan sebagai beton normal $\left(\mathrm{y}=2.400 \mathrm{~kg} / \mathrm{m}^{3}\right)$ dan beton berat $\left(\mathrm{y}=3.000 \mathrm{~kg} / \mathrm{m}^{3}\right)$.

\section{Penelitian Terdahulu}

Karakteristik campuran beton aspal dengan penambahan abu slag baja sebagai bahan pengganti filler menghasilkan nilai stabiblitas semakin meningkat jika abu slag semakin banyak, nilai fleksibilitas semakin bertambah seiring bertambahnya kadar abu slag, namun stabilitas mengalami penurunan jika kadar abu slag ditingkatkan [3].

\section{Persiapan Bahan}

Sebelum melaksankan penelitian, terlebih dahulu dilakukan persiapan material yang akan diteliti di laboratorium. Bahan yang digunakan dalam penelitian ini adalah :

\section{a. Agregat}

Agregat kasar (Slag Nikel) diperoleh dari Soroako Kabupaten Luwu Timur. Dan agregat halus (batu becah) diperoleh dari Malili Kabupaten Luwu Timur. Pengambilan sampel dilakukan untuk mendapatkan contoh material yang akan diperiksa di laboratorium dan dapat mewakili seluruh bahan yang tersedia.

\section{b. Aspal Minyak}

Adapun aspal minyak yang digunakan adalah aspal dengan penetrasi 60/70.

\section{c. Filler}

Dalam penelitian ini digunakan jenis Filler yaitu semen Portland. Semen portland yang di gunakan adalah Semen Tonasa type I. Dari Kabupaten Pangkep Propinsi Sulawesi Selatan.
Pemanfaatan limbah plastik sebagai bahan tambah campuran aspal pada perkerasan jalan AC-WC terhadap nilai Marshall menghasilkan dengan dilakukannya penambahan plastik jenis Low Density Poliethylene sebanyak 4\% dapat digunakan untuk campuran AC - WC tetapi penambahan 6\% akan menunjukkan nilai pelelehan yang terlalu kecil sehingga tidak dapat digunakan untuk lapisan AC WC [4].

Pemanfaatan Tanah Domato sebagai filler dalam campuran aspal panas HRS-WC menghasilkan nilai stabilitas $1754.36 \mathrm{~kg}$, flow 3,55 mm, Quotient Marshall $494.32 \mathrm{~kg} / \mathrm{mm}$, VIM 5,74 \%, VMA $23.72 \%$, VFB $75.83 \%$ yang masih memenuhi batas spesifikasi [5].

Potensi penggunaan limbah kelapa sawit sebagai agregat pengisi campuran menghasilkan abu serat kelapa sawit dan abu cangkang kelapa sawit berpotensi tahan terhadap deformasi namun kurang tahan terhadap retak karena tarik [6].

\section{METODOLOGI PENELITIAN}

\section{Metode Penelitian}

Adapun metode yang digunakan dalam penelitian ini dengan mengadakan kegiatan percobaan di laboratorium dengan dasar menggunakan sistem pencampuran aspal panas Hot Rolled Sheet-Base (HRS-Base) yang menggunakan Slag nikel sebagai bahan pengganti.

\section{Karakteristik Bahan}

a. Pemeriksaan Agregat Kasar

Pemeriksaan analisa saringan agregat

Pemeriksaan kekuatan Agregat Terhadap

Pengujuan keausan dengan alat Abrasi Los Angeles

Pemeriksaan berat jenis dan penyerapan agregat

Pengujian indeks kepipihan dan kelonjongan

Pemeriksaan penurunan kelekatan agregat terhadap aspal

b. Pemeriksaan Agregat Halus

Pemeriksaan analisa saringan

Pemeriksaan berat jenis dan penyerapan agregat

Pemeriksaan kadar lumpur pasir

Pemeriksaaan berat jenis Filler (semen)

Pemeriksaaan material lolos saringan no.200

c. Pemeriksaan Aspal 


Pemeriksaan penetrasi aspal sebelum
kehilangan berat
Pemeriksaan penetrasi aspal sesudah
kehilangan berat
Pemeriksaan daktalitas

\section{HASIL DAN PEMBAHASAN}

\section{HRS-Base Gradasi Senjang dan Semi Senjang}

\section{a. Analisis Terhadap VIM Gradasi Senjang}

Semakin tinggi kadar aspal yang digunakan maka nilai VIM akan semakin kecil (berkurang). Hubungan VIM dan kadar aspal lataston HRS-Base gradasi senjang dapat dilihat pada Gambar 2.

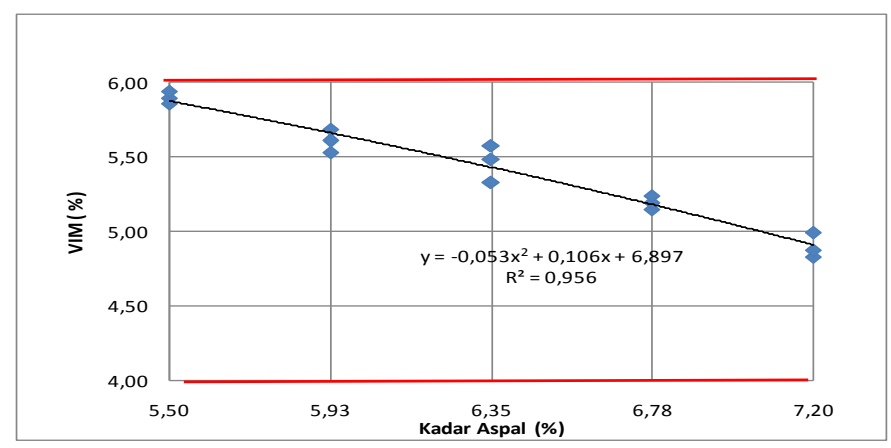

Gambar 2. Grafik hubungan VIM dan kadar aspal Lataston HRS-Base gradasi senjang

\section{b. Analisis Terhadap VIM Gradasi Semi Senjang}

Semakin tinggi kadar aspal yang digunakan maka nilai VIM akan semakin kecil (berkurang). Hubungan VIM dan kadar aspal lataston HRS-Base gradasi semi senjang dapat dilihat pada Gambar 3.

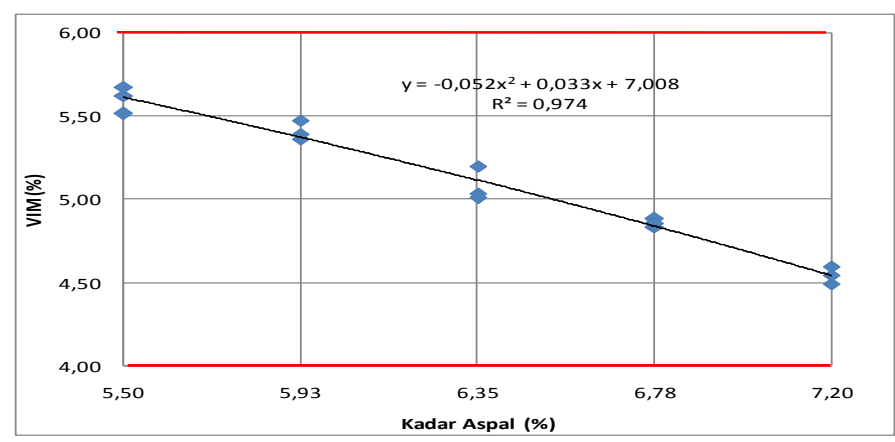

Gambar 3. Grafik hubungan VIM dan kadar aspal Lataston HRS-Base gradasi semi senjang

\section{c. Analisis Terhadap Stabilitas Gradasi Senjang}

Semakin banyak penggunaan aspal akan mempengaruhi kekuatan / stabilitas campuran.stabilitas meningkat sampai kadar aspal $6,35 \%$, tetapi jika kadar aspal bertambah lagi maka stabilitasnya akan menurun (berkurang). Hubungan
Pemeriksaan titik lembek aspal dan ter Pemeriksaan titik nyala dan titik bakar Pemeriksaan kehilangan berat Pemeriksaan berat jenis aspal.

stabilitas dan kadar aspal Lataston HRS-Base gradasi senjang disajikan pada Gambar 4.

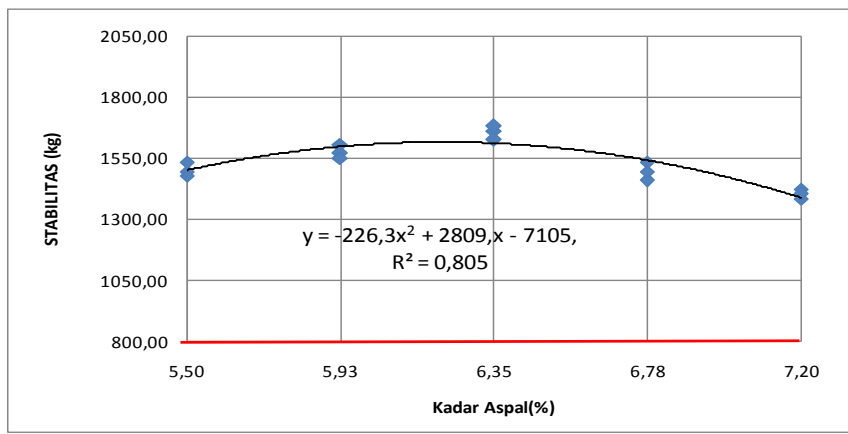

Gambar 4. Grafik hubungan stabilitas dan kadar aspal Lataston HRS-

Base gradasi senjang

\section{d. Analisis Terhadap Stabilitas Gradasi Semi Senjang}

Semakin banyak penggunaan aspal akan mempengaruhi kekuatan / stabilitas campuran.stabilitas meningkat sampai kadar aspal $6,35 \%$, tetapi jika kadar aspal bertambah lagi maka stabilitasnya akan menurun (berkurang). Hubungan stabilitas dan kadar aspal lataston HRS-Base gradasi semi senjang disajikan pada Gambar 5.

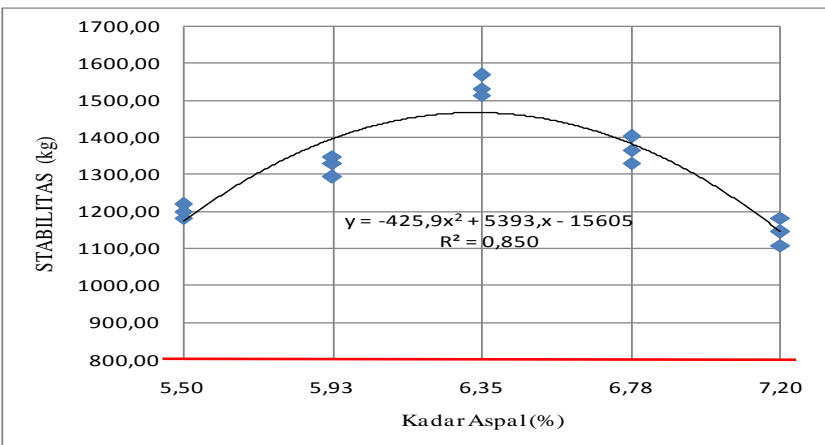

Gambar 5. Grafik Hubungan Stabilitas dan Kadar Aspal Lataston HRS-Base Gradasi semi senjang

\section{e. Analisis Flow Gradasi Senjang}

Nilai Flow akan menurun sampai kadar aspal 6,35\% tetapi apabila kadar aspalnya bertambah lagi maka flow/kelenturannya akan meningkat. Hubungan flow dan kadar aspal lataston HRS-Base gradasi senjang dapat dilihat pada Gambar 6. 


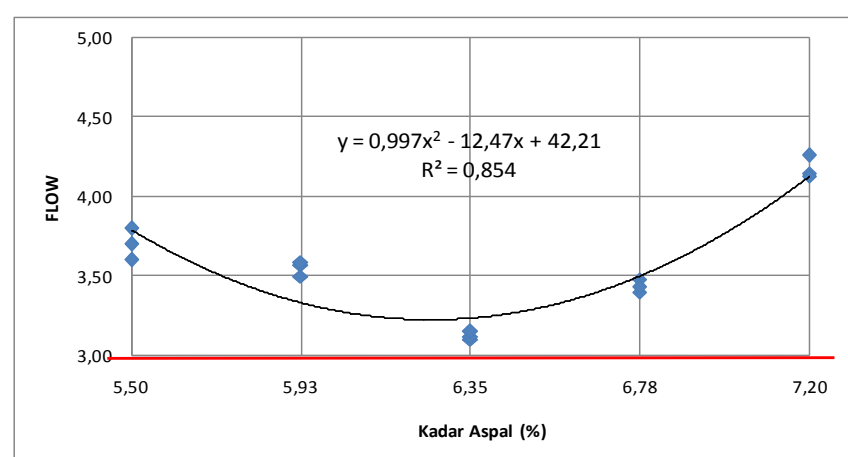

Gambar 6. Grafik hubungan flow dan kadar aspal Lataston HRS Base gradasi senjang

\section{f. Analisis Flow Gradasi Semi Senjang}

Nilai Flow akan menurun sampai kadar aspal 6,35\% tetapi apabila kadar aspalnya bertambah lagi maka flow/kelenturannya akan meningkat. Hubungan flow dan kadar aspal lataston HRS Base gradasi semi senjang dapat dilihat pada Gambar 7 .

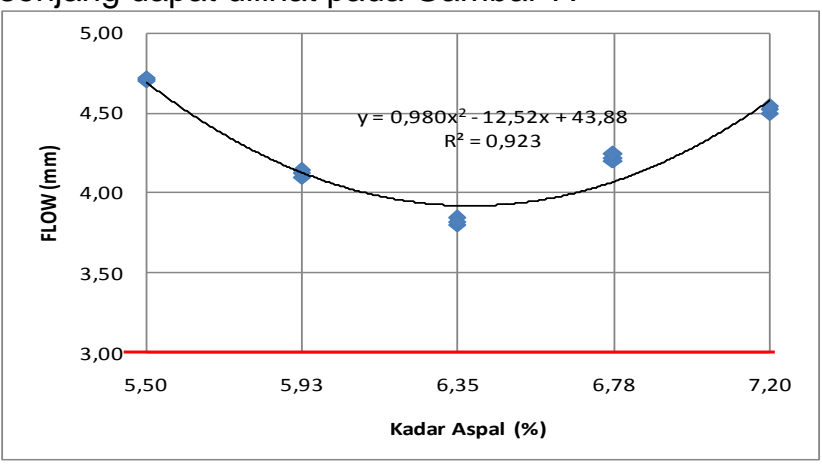

Gambar 7. Grafik Hubungan flow dan kadar aspal Lataston HRS Base gradasi semi senjang

\section{g. Analisis VMA Gradasi Senjang}

Semakin banyak penggunaan aspal dalam campuran maka nilai VMA/rongga di dalam butiran agregat yang terisi oleh aspal akan semakin tinggi juga. Hubungan VMA dan kadar aspal lataston HRS-Base gradasi senjang dapat dilihat pada Gambar 8.

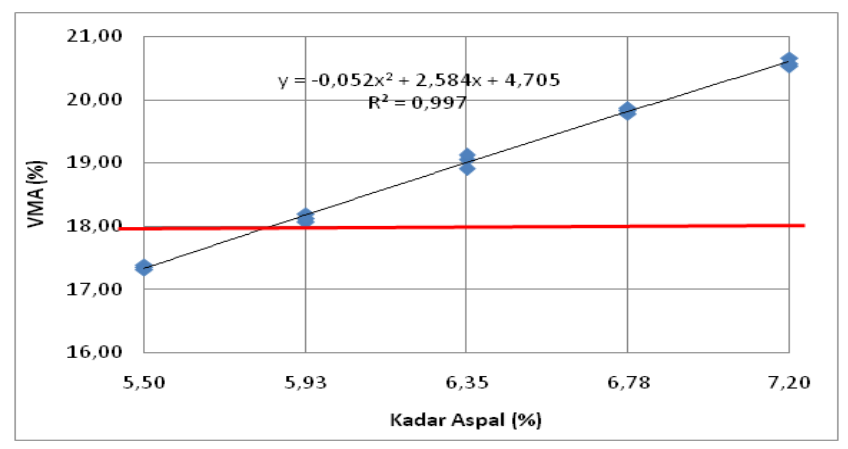

Gambar 8. Grafik hubungan VMA dan kadar aspal Lataston HRS-Base gradasi senjang

h. Analisis VMA Gradasi Semi Senjang

Semakin banyak penggunaan aspal dalam campuran maka nilai VMA/rongga di dalam butiran agregat yang terisi oleh aspal akan semakin tinggi juga. Hubungan VMA dan kadar aspal lataston HRS-Base gradasi semi senjang dapat dilihat pada Gambar 9.

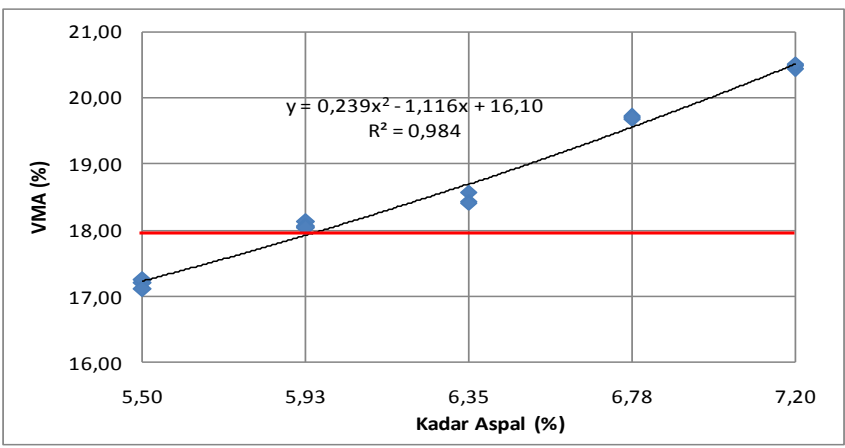

Gambar 9. Grafik hubungan VMA dan kadar aspal Lataston HRS- Base gradasi semi senjang

i. Analisis Terhadap VFB Gradasi Senjang

Semakin banyak penggnaan aspal maka nilai rongga dalam campuran dan dalam agregat yang terisi aspal (VFB) kan semakin banyak. Hubungan VFB dan kadar Filler HRS-Base gradasi senjang dapat dilihat pada Gambar 10.

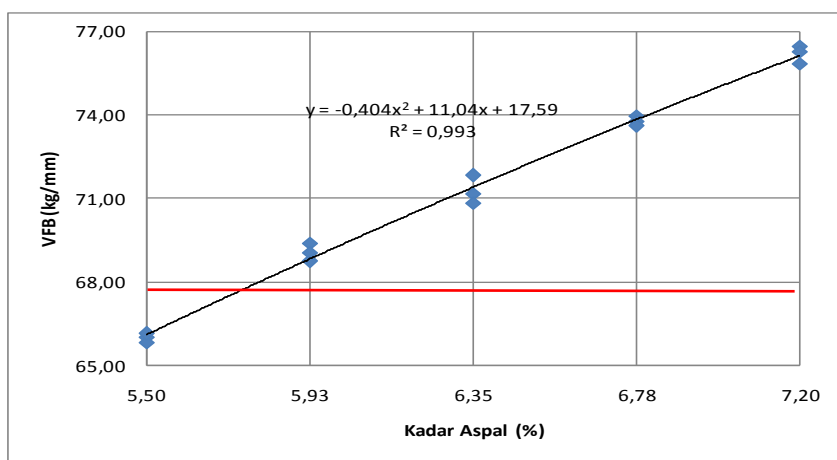

Gambar 10.Grafik Hubungan VFB dan kadar filler HRS-Base senjang

\section{j. Analisis Terhadap VFB Gradasi Semi Senjang}

Semakin banyak penggnaan aspal maka nilai rongga dalam campuran dan dalam agregat yang terisi aspal (VFB) kan semakin banyak. Hubungan VFB dan kadar Filler HRS-Base gradasi semi senjang dapat dilihat pada Gambar 11.

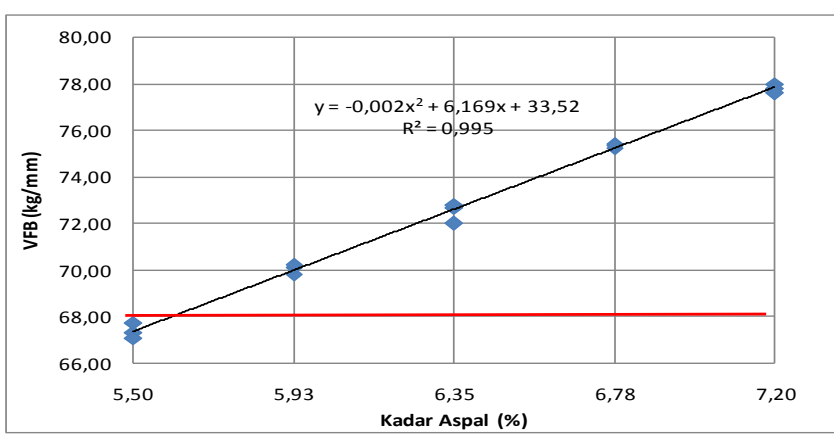

Gambar 11.Grafik hubungan VFB dan kadar filler HRS-Base semi senjang 
k. Penentuan Proporsi Kadar Aspal pada Campuran Lataston HRS-Base Gradasi Senjang

Untuk penentuan nilai optimum untuk Marshall Immersion, kadar aspal yang digunakan yaitu 6,35\%. Untuk Lataston HRS-Base gradasi senjang lebih cenderung kepada kekuatan atau stabilitas yang menopang atau menahan lapisan diatasnya sehingga kadar aspal 6,35\% yang diambil karena memiliki stabilitas yang tinggi di antara campuran kadar aspal yang lainnya. Diagram analisis kadar aspal optimum campuran lataston HRS-Base gradasi senjang dapat dilihat pada Gambar 12.

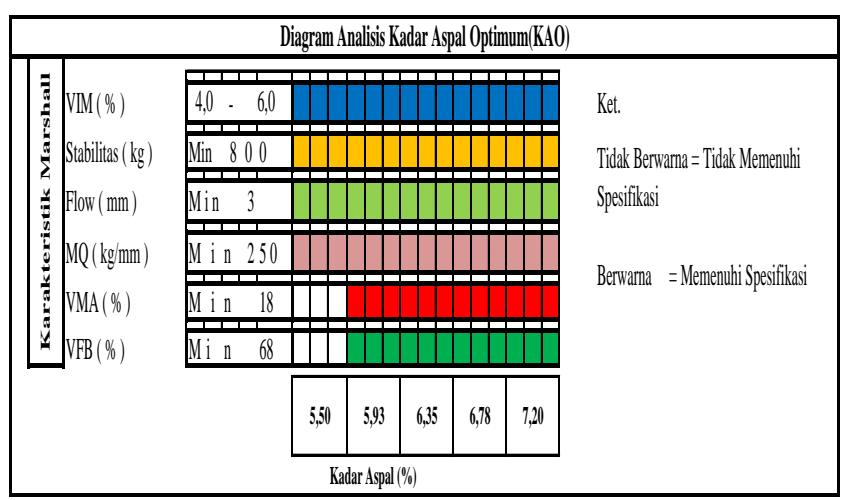

Gambar 12. Diagram analisis kadar aspal optimum campuran Lataston HRS -Base senjang

I. Indeks Perendaman (Marshall Immertion)

Marshall immertion adalah salah satu pengujian untuk melihat satbilitas dan ketahanan campuran atau keawetan suatu campuran. Indeks perendaman dapat dilihat pada Tabel 1 dan Gambar 13..

Tabel 1. Indeks perendaman Marshall Immertion

\begin{tabular}{|c|c|c|c|c|}
\hline $\begin{array}{c}\text { Benda } \\
\text { Uji }\end{array}$ & $\begin{array}{c}\text { Proporsi } \\
\text { aspal } \\
(\%)\end{array}$ & $\begin{array}{c}\text { Stabilitas } \\
\text { Marshall } \\
\text { Immertion } \\
(\mathrm{kg})\end{array}$ & $\begin{array}{c}\text { Stabilitas } \\
\text { Marshall } \\
\text { Konvensional } \\
(\mathrm{kg})\end{array}$ & $\begin{array}{c}\text { Indeks perendaman } \\
\text { IP. (\%) }\end{array}$ \\
\hline 1. & 6,35 & 1661,82 & 1606,43 & 96,67 \\
\hline 2. & 6,35 & 1624,89 & 1587,96 & 97,73 \\
\hline 3. & 6,35 & 1680,29 & 1624,89 & 96,70 \\
\hline \multicolumn{2}{|c|}{ Rata - Rata } & $\mathbf{1 6 5 5 , 6 7}$ & $\mathbf{1 6 0 6 , 4 3}$ & $\mathbf{9 7 , 0 3}$ \\
\hline
\end{tabular}

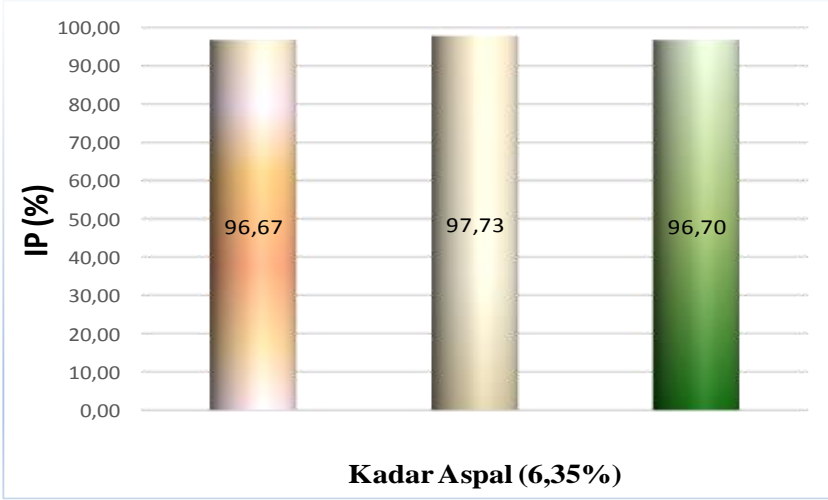

Gambar 13. Indeks perendaman Marshall Immertion

m. Penentuan proporsi kadar aspal pada campuran Lataston HRS-Base gradasi semi senjang.

Untuk penentuan nilai optimum untuk Marshall Immertion, kadar aspal yang digunakan yaitu $6,35 \%$. Untuk Lataston HRS-Base gradasi semi senjang lebih cenderung kepada kekuatan atau stabilitas yang menopang atau menahan lapisan diatasnya sehingga kadar aspal 6,35\% yang diambil karena memiliki stabilitas yang tinggi di antara campuran kadar aspal yang lainnya. Diagram analisis kadar aspal optimum dapat dilihat pada Gambar 14.

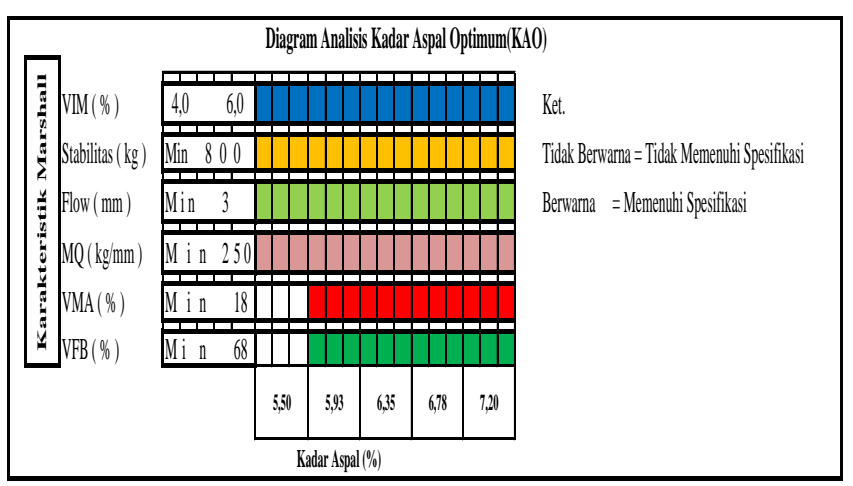

Gambar 14. Diagram analisis kadar aspal optimum Campuran Lataston HRS - Base gradasi semi senjang

\section{n. Indeks Perendaman (Marshall Immertion)}

Marshall Immertion adalah salah satu pengujian untuk melihat durabilitas (ketahanan terhadap beban dan pengaruh suhu pada campuran yang terendam air) atau keawetan suatu campuran, hasil dari pengujian. Indeks perendaman Marshall Immertion gradasi semi senjang dapat dilihat pada Tabel 2 dan Gambar 15. 
Tabel 2. Indeks perendaman Marshall Immertion gradasi semi senjang

\begin{tabular}{|c|c|c|c|c|}
\hline $\begin{array}{c}\text { Benda } \\
\text { Uji }\end{array}$ & $\begin{array}{c}\text { Proporsi aspal } \\
(\%)\end{array}$ & $\begin{array}{c}\text { Stabilitas } \\
\text { Marshall } \\
\text { Immertion }(\mathrm{kg})\end{array}$ & $\begin{array}{c}\text { Stabilitas } \\
\text { Marshall } \\
\text { Konvensional } \\
(\mathrm{kg})\end{array}$ & $\begin{array}{c}\text { Indeks } \\
\text { perendaman } \\
\text { IP }(\%)\end{array}$ \\
\hline 1. & 6,35 & 1569,50 & 1532,57 & 97,65 \\
\hline 2. & 6,35 & 1532,57 & 1514,11 & 98,80 \\
\hline & 6,35 & 1514,11 & 1477,18 & 97,56 \\
\hline 3. & & $\mathbf{1 5 3 8 , 7 3}$ & $\mathbf{1 5 0 7 , 9 5}$ & $\mathbf{9 8 , 0 0}$ \\
\hline \multicolumn{2}{|r|}{ Rata - Rata } & & & \\
\hline
\end{tabular}

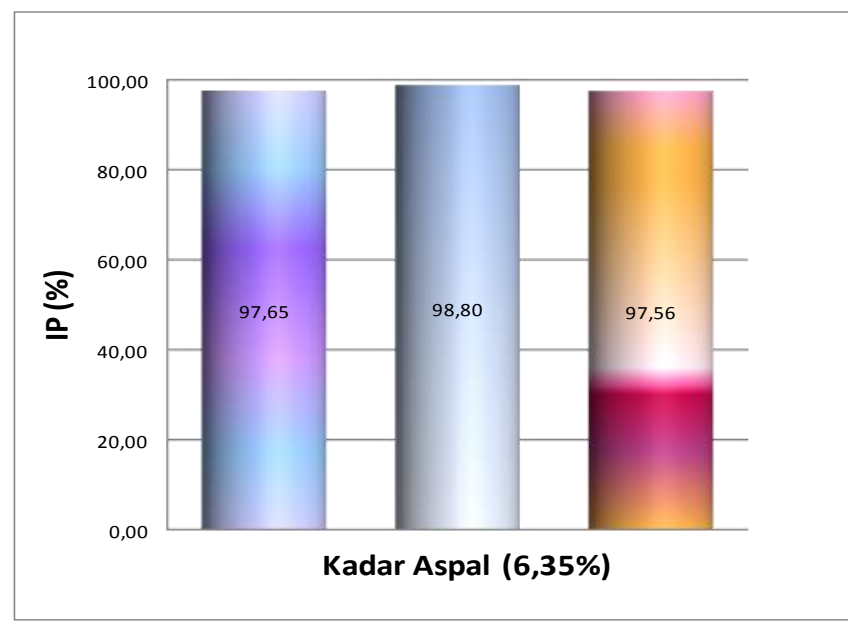

Gambar 15. Grafik hubungan Marshall Immertion dan kadar aspal optimum untuk HRS-Base gradasi semi senjang

\section{KESIMPULAN}

Karakteristik Slag Nikel yang berasal dari Soroako, Luwu Utara untuk campuran Lataston HRS-Base bergradasi senjang dan semi senjang memenuhi standar spesifikasi Bina Marga.

Komposisi campuran Lataston HRS-Base Gradasi senjang yaitu agregat kasar $20,38 \%$, agregat halus $68.83 \%$, Filler $4.44 \%$, dan aspal $6.35 \%$, sedangkan untuk Lataston HRS-Base Gradasi semi senjang yaitu agregat kasar $35.69 \%$, agregat halus $52.87 \%$, Filler $5.09 \%$ dan aspal $6.35 \%$.
Nilai karakteristik Marshall Konvensional campuran Lataston HRS-Base senjang dan semi senjang telah memenuhi standar spesifikasi Bina Marga dengan menggunakan kadar aspal optimum $6.35 \%$.

Marshall Immertion diperoleh Indeks Perendaman atau Indeks Kekuatan sisa (IKS) $97.03 \%$ untuk Lataston HRS-Base Senjang dan $98.00 \%$ untuk Lataston HRS-Base Semi Senjang, yang artinya campuran tahan terhadap suhu, lamanya perendaman dan terendam air yang menggunakan slag nikel sebagai pengganti agregat kasar dari Soroako Luwu Timur.

\section{DAFTAR PUSTAKA}

[1] "Perkerasan lentur jalan raya / Penyusun Silvia Sukirman." [Online]. Available: http://library.um.ac.id/free-

contents/index.php/buku/detail/perkerasanlentur-jalan-raya-penyusun-silvia-sukirman27261.html.

[2] "Spesifikasi Umum Bina Marga Divisi 62010 Perkerasan Aspal." [Online]. Available: https://www.scribd.com/doc/52889551/Spesifikas i-Umum-Bina-Marga-Divisi-6-2010-Perk-ErasAn-Aspal.

[3] N. Hartatik, G. S. Utami, and N. Rohmania, "Karakteristik Campuran Beton Aspal (AC-WC) Dengan Penambahan Abu Slag Baja Sebagai Bahan Pengganti Filler," p. 14.

[4] D. Oleh, "Pemanfaatan Limbah Plastik Sebagai Bahan Tambah Campuran Aspal Pada Perkerasan Jalan Ac-WC Terhadap Nilai Marshall," p. 58.

[5] M. R. E. Manoppo, S. O. Dapas, and D. R. Walangitan, "Pemanfaatan Tanah Domato Sebagai Filler Dalam Campuran Aspal Panas HRS-WC," p. 6, 2016.

[6] L. B. Suparma, T. W. Panggabean, and S. Mude, "Potensi Penggunaan Limbah Kelapa Sawit Sebagai Agregat Pengisi Pada Campuran," vol. 14, no. 2, p. 10. 